\title{
PENGARUH LAMA PENYIMPANAN TERHADAP KUALITAS TELUR KONSUMSI AYAM KAMPUNG DAN AYAM LOHMAN BROWN
}

\author{
WIDYANTARA, P. R. A. ${ }^{1)}$, G.A.M. KRISTINA DEWI ${ }^{2)}$, I N. T. ARIANA ${ }^{2)}$ \\ 1) Mahasiswa Program Studi Magister Peternakan Pascasarjana Universitas Udayana, \\ 2) Fakultas Peternakan Universitas Udayana, Denpasar Bali \\ e-mail : Noesena@ymail.com
}

\begin{abstract}
ABSTRAK
Penelitian ini bertujuan untuk mengetahui pengaruh lama penyimpanan terhadap kualitas telur ayam kampung dan ayam Lohman Brown. Rancangan acak lengkap (RAL) pola faktorial dengan 2 faktor perlakuan yaitu telur ayam kampung dan ayam Lohmnan Browm dengan 4 faktor lama penyimpanan o, 7, 14, 21 hari pada suhu ruang dan 3 kali ulangan dan setiap ulangan terdiri dari 10 butir telur digunakan dalam penelitian ini. Hasi penelitian berupa telur dengan kualitas yang baik dengan lama penyimpanan yang optimal dengan menguji eksterior telur dan interior telur seperti indeks telur, warna kuning telur, $\mathrm{pH}$, Haugh Unit telur serta kandungan atau populasi mikroba yang tumbuh selama penyimpanan. Hasil penelitian menunjukkan terjadi perbedaan yang nyata $(\mathrm{P}<0,05)$ pada eksterior yaitu pada kebersihan dan tekstur permukaan telur, dan pada interior juga berbeda nyata secara statistik pada HU telur, sedangkan perlakuan yang lainya tidak berbeda $(\mathrm{P}>0,05)$. Dapat disimpulkan bahwa perlakuan penyimpanan o, 7, 14, 21 hari pada telur ayam kampung dan telur ayam Lohman Brown secara eksterior dan interior mengalami penurunan kualitas namun masih layak dikonsumsi hingga lama penyimpanan 21 hari dalam suhu ruang serta masih menunjukkan nilai grade A dan cemaran mikroba masih dibawah Standar Nasional Indonesia (SNI).
\end{abstract}

\section{Kata kunci: ayam Lohman Brown, Haugh Unit, kualitas telur, penyimpanan, telur ayam kampong \\ THE EFFECT OF STORAGE DURATION ON EGGS CONSUMPTION QUALITY OF KAMPUNG CHICKEN AND LOHMAN BROWN}

\begin{abstract}
The research as conducted to know the influence of eggs prolonged storage on egg quality of kampung chicken and Lohman Brown. The methods used was Randomized Complete Design of Factorial Pattern (RAL) with two treatments, Kampung chicken and chickens Lohman Brown eggs. Four factors duration of storage, consists of o, 7, 14, 21 days at room temperature with three replications and ten eggs in each replications. The results of good quality of eggs found with optimal retention by testing exterior and interior of eggs, as of: index of egg, yolk colour, $\mathrm{pH}$, Haugh Unit and egg content or microbe population during storage. It showed that differences occurred on the exterior $(\mathrm{P}<0.05)$ such as: texture and hygiene of egg. In contrast, statistic differences also found in the interior as in the real HU eggs, other treatments did not differ $(\mathrm{P}>0.05)$. This can be concluded that $0,7,14,21$ days treatment of storage on chicken Kampung and Lohman Brown eggs decline but still worth to be consumed up to 21 days of prolonged storage in room temperature. Besides, the value of A grade and microbial impurities are still under the Indonesia national standard (SNI).
\end{abstract}

Keywords: Lohman Brown chicken, Haugh Unit, quality of egg, storage egg, kampung chicken

\section{PENDAHULUAN}

Sumber daya manusia berkualitas dapat dicapai apabila asupan makanan yang dikonsumsi cukup dan bergizi. Menurut Sarwono (1995) bahwa pentingnya telur sebagai bahan makanan karena banyaknya zat pembangun (protein) yang terdapat di dalamnya dan itu telur juga merupakan bahan makanan yang paling mudah dicerna. Menurut Sarwono (1995) bahwa pentingnya telur sebagai bahan makanan karena banyaknya zat pembangun (protein) yang terdapat didalamnya dan telur juga merupakan bahan makanan yang paling mudah dicerna. Kondisi ekonomi masyarakat sangat mempengaruhi tingkat konsumsi, sehingga masyarakat membutuhkan sumber gizi yang harganya terjangkau.

Kualitas telur adalah sesuatu yang dinilai, dilihat 
dan diamati pada telur untuk perbandingan baik atau tidaknya telur sehingga dapat dipergunakan untuk kebutuhan konsumen. Kualitas eksternal dilihat pada kebersihan kulit, tekstur dan bentuk telur, sedangkan kualitas internal dilihat pada putih bentuk kuning telur dan kekuatan kuning telur. Penurunan kualitas interior dapat diketahui dengan menimbang bobot telur atau meneropong ruang udara (air cell) dan dapat juga dengan memecah telur untuk diperiksa kondisi kuning telur dan putih telur (HU) (Stadelman dan Cotteril, 1973). Indeks putih telur segar berkisar 0,050 - 0,174 sesuai dengan standar SNI 01-3926-2008 (BSN, 2008). Semakin tua umur telur, maka diameter putih telur akan melebar sehingga indeks putih telur semakin kecil. Perubahan ini disebabkan pertukaran gas antara udara luar dengan isi telur melalui pori-pori kerabang telur dan penguapan air akibat dari lama penyimpanan, suhu, kelembaban dan porositas kerabang telur (Yuanta, 2010). Pada cangkang telur sering terdapat tinja (feses) yang merupakan habitat bakteri koliform. Bakteri ini masuk melalui cangkang secara osmosi. Menurut Pelczar dan Chan (1988) beberapa bakteri seperti Echeriscia coli dan Salmonella yang banyak menimbulkan gangguan kesehatan bagi manusia. Spesies seperti Salmonella dapat menembus pori-pori cangkang telur dan masuk kedalam telur. Cangkang telur sendiri mudah retak dan pecah sehingga sering terjadi kontaminasi bakteri (Jamila et al., 2009).

Mempertahankan kualitas telur agar tetap segar mulai dari produsen sampai ke konsumen, merupakan masalah utama dalam pemasaran telur. Kemungkinan penurunan kualitas bukan hanya disebabkan oleh faktor penanganan dan kondisi lingkungan di tingkat pemasaran. Menurut Hadiwiyoto (1983), telur segar adalah telur yang baru diletakkan induk ayam disarangnya, mempunyai daya simpan yang pendek, makin lama makin turun kesegarannya. Kesegarannya menurun setelah berumur lebih dari satu minggu, ditandai apabila dipecah isinya sudah tidak dapat mengumpul lagi. Penurunan kesegaran telur tersebut terutama disebabkan oleh adanya kontaminasi mikrobia dari luar, masuk melalui pori-pori kerabang.

Penelitian ini bertujuan untuk mengetahui pengaruh penyimpanan terhadap kualitias telur ayam kampung dan ayam ras.

\section{MATERI DAN METODE}

\section{Lokasi dan Waktu Penelitian}

Penelitian ini akan dilaksanakan selama 3 bulan dari bulan Januari hingga Maret 2016 di Laboratorium Terpadu Nutrisi dan Makanan Ternak, dan Laboratorium Teknologi Hasil Ternak dan Mikrobiologi Ternak, Fakultas Peternakan, Universitas Udayana, Denpasar.

\section{Rancangan Penelitian}

Rancangan penelitian yang digunakan dalam penelitian ini adalah rancangan acak lengkap (RAL) pola faktorial $(2 \times 4)$ dimana:

a. Faktor 1 adalah telur ayam kampung dan ayam Lohman Brown.

b. Faktor 2 adalah lama penyimpanan: o, 7, 14, dan 21 hari dengan

3 kali ulangan dan setiap ulangan terdiri dari 10 butir telur dengan total telur yang digunakan sebanyak 240 butir

\section{Variabel Penelitian}

\section{Mikrobiologi Telur}

Batas maksimum cemaran mikroba dalam bahan makanan dan telur dalam CFU (Colony forming unit)/g.

\begin{tabular}{cccc}
\hline Total Mikroba & Telur segar & Telur kering & Telur beku \\
\cline { 2 - 4 } & $110^{5}$ & $<2,5 \times 10^{3}$ & $<2,5 \times 10^{3}$ \\
$<1 \times 10^{2}$ & $<1 \times 10^{1}$ & $<1 \times 10^{1}$ \\
$1 \times 10^{1}$ & $<1 \times 10^{1}$ & $<1 \times 10^{1}$
\end{tabular}

Anonimus (2007).

Variabel yang diamati adalah jumlah total Total Plate Count (TPC) selama penyimpanan. Jumlah bakteri yang dihitung:

1 Faktor pengencer $x$ volume inokulan $C F U \mathrm{ml}$

Kualitas exterior telur, meliputi:

1. Berat telur, berat telur ditimbang sebelum penyimpanan dan setelah penyimpanan dengan timbangan untuk mengetahui perbedaan berat telur.

2. Kebersihan kerabang telur, kebersihan telur meliputi ada tidaknya kotoran sisa kotoran tinja/ feses yang menempel dicangkang telur, semakin kotor cangkang telur semakin rendah nilainya.

3.Permukaan telur, penilaian pada permukaan telur dilihat dari bentuk telur, permukaan telur yang kasar atau halus.

4. Indeks Telur, Panjang dan lebar masing2 telur di ukur dengan menggunakan jangka sorong, Indeks telur $=$

Kualitas interior telur, meliputi:

1. $\mathrm{pH}$ telur, putih dan kuning telur dicampur kedalam gelas ukur kemudian diaduk hingga homogen dan diukur dengan $\mathrm{pH}$ meter

2.Tebal dan berat kerabang, telur yang sudah dipecahkan kemudian diambil kerabangnya dan diukur ketebalannya dengan Jangka sorong dan Micrometer dan kemudian kerabang ditimbang dengan timbangan digital.

3. Warna kuning telur, untuk menentukan warna kuning telur tersebut dengan Egg Yolk Colour Fan. 
4.HU / Haugh Unit, telur ditimbang beratnya lalu dipecah secara hati-hati dan diletakkan ditempat datar. Ketebalan putih telur (mm) diukur dengan mikrometer. Bagian putih telur yang diukur dipilih diantara pinggir kuning telur dan pinggir putih telur (Sudaryani, 2003). Kemudian dihitung Haugh Unit dengan rumus:

$\mathrm{HU}=100 \log \left(\mathrm{H}+7,57-1,7 \mathrm{~W}^{0,37}\right)$

Keterangan:

$\mathrm{HU}=$ Haugh Unit

$\mathrm{H}=$ tinggi putih telur kental

$\mathrm{W}=$ berat telur

Menurut Sudaryani (1996), semakin tinggi nilai HU menunjukan semakin baik kualitas telur.

1. Tingkat AA memiliki skor $>72 \mathrm{HU}$

2. Tingkat A memliki skor $62-72 \mathrm{HU}$.

3. Tingkat B memiliki skor $<60 \mathrm{HU}$

\section{Analisis Statistik}

Data yang didapat kemudian dianalisis dengan sidik ragam (Anova), apabila terdapat interaksi $(\mathrm{P}<0,05)$ dilanjutkan dengan uji Duncan's (Sastrosupadi, 2000) dengan bantuan program SPSS 17.

\section{HASIL DAN PEMBAHASAN}

Hasilpenelitian menunjukkantidakterjadiperbedaan yang nyata $(\mathrm{P}>0,05)$ pada berat telur ayam kampung dimana pada Ho lebih tinggi dari pada disimpan 7 hari (H7), disimpan selama 14 hari (H14) dan disimpan selama 21 hari (H21) berturut-turut 40,61; 40,23; dan 40,56 (Tabel 1) dan telur ayam Lohman disimpan 1 hari (Ho), disimpan selama 7 hari ( $\mathrm{H} 7)$, disimpan selama 14 hari (H14), disimpan selama 21 hari (H21) berturutturut 63,$60 ; 63,04 ; 63,09 ; 63,09$ (Tabel 1), interaksi antara telur ayam kampung dan ayam Lohman tidak berpengaruh terhadap berat telur.

Pada telur ayam Lohman terjadi pengaruh yang tidak berbeda nyata $(\mathrm{P}>0,05)$, hal ini disebabkan induk ayam telah mendapat jumlah protein untuk dikonsumsi mencukupi kebutuhan untuk mencapai berat telur yang optimal. Berat telur juga dipengaruhi oleh genetik, dimana ayam kampung dengan kemampuan genetik rendah hanya akan mampu menghasilkan telur yang optimal sesuai kemampuannya dibanding dengan ayam Lohman. Ayam mampu mengefisienkan penggunaan ransum, sehingga bila terjadi defisiensi zat makanan, kebutuhannya dapat terpenuhi dengan merombak zatzat makanan dari tubuhnya (Sudaryani, 2000).

Penurunan berat telur ayam kampung dan ayam Lohman merupakan salah satu perubahan yang nyata selama penyimpanan dan berkorelasi hampir linier terhadap waktu di bawah kondisi lingkungan yang konstan. Kecepatan penurunan berat telur dapat diperbesar pada suhu tinggi dan kelembaban rendah. Kehilangan berat sebagian besar disebabkan oleh penguapan air terutama pada bagian albumen, dan sebagian kecil penguapan gas-gas seperti $\mathrm{CO}_{2}, \mathrm{NH}_{3}$, $\mathrm{N}_{2}$, dan sedikit $\mathrm{H}_{2} \mathrm{~S}$ akibat degradasi komponen protein telur (Kurtini et al., 2011). Telur ayam Lohman yang disimpan pada suhu ruang dengan kelembaban udara yang rendah akan mengalami penyusutan berat lebih cepat dibandingkan dengan telur ayam Lohman yang disimpan pada suhu ruang dengan kelembaban udara yang tinggi. Hal ini disebabkan oleh kelembaban yang rendah selama penyimpanan akan mempercepat penguapan karbondioksida dan air dari dalam telur, sehingga penyusutan berat akan lebih cepat (Stadelman dan Cotterill, 1995).

Kebersihan telur dari perlakuan menunjukkan hasil yang berbeda nyata $(\mathrm{P}<0,05)$ pada telur ayam kampung, dimana $\mathrm{H}_{7}$ menunjukan angka tertinggi $(0,38)$ sedangkan dari Ho, H14, H21 berturut-turut 0,33, 0,25 dan 0,11 lebih rendah dari H7. Pada telur ayam Lohman pada $\mathrm{Ho}, \mathrm{H} 7, \mathrm{H} 14, \mathrm{H} 21$ berturut-turut 0,12; 0,15; 0,16; dan 0,19 dimana secara statistik tidak berbeda nyata $(\mathrm{P}>0,05)$ (Tabel 1). Interaksi antara telur ayam kampung dan ayam Lohman Brown berpengaruh signifikan terhadap kebersihan permukaan telur. Hasil analisis tekstur permukaan telur menunjukkan hasil yang berbeda nyata $(\mathrm{P}<0,05)$.

Interaksi antara telur ayam Kampung dan ayam Lohman Brown berpengaruh terhadap kebersihan telur yang disebabkan oleh udara yang masuk membawa partikel debu yang menempel pada telur, dimana setiap harinya semakin bertambah debu yang menempel pada telur. Penurunan kebersihan juga dapat disebabkan oleh sisa kotoran yang menempel pada telur pada saat pengambilan telur dari kandang, dimana kotoran tersebut mengering dan mengeras pada cangkang telur. Sedangkan pada ayam Lohman Brown hasil yang didapat menunjukan tidak berbeda nyata $(\mathrm{P}>0,05)$ hal ini dikarenakan telur yang keluar dari induknya langsung menuju ke tempat telur yang ada di kandang ayam sehingga meminimalisir kotoran menempel pada telur, walaupun udara yang membawa partikel debu menempel selama penyimpanan tetapi penurunan kebersihan telur menunjukan hasil yang tidak berbeda nyata.

Tekstur permukaan pada telur ayam Kampung menunjukkan hasil yang berbeda nyata $(\mathrm{P}<0,05)$ dimana $\mathrm{H} 7$ menunjukkan angka tertinggi (o,30), sedangkan perlakuan Ho, H14, dan H21 berturut-turut o,26; 0,12; 0,11 lebih rendah dari perlakuan H7. Sedangkan pada telur ayam Lohman Brown pada perlakuan pada telur ayam Lohman Brown pada Ho, H7, H14, H21 berturutturut 0,$12 ; 0,16 ; 0,17$; dan 0,19 dimana secara statistik tidak berbeda nyata $(\mathrm{P}>0,05)$ (Tabel 1) dan interaksi 
Tabel 1. Pengaruh penyimpanan terhadap kualitas eksterior telur ayam kampung dan ayam Lohman Brown

\begin{tabular}{|c|c|c|c|c|c|c|c|c|c|c|}
\hline \multirow{3}{*}{ Variabel } & \multicolumn{10}{|c|}{ Perlakuan } \\
\hline & \multicolumn{4}{|c|}{$\begin{array}{c}\text { Ayam Kampung } \\
\text { Penyimpanan (Hari) }\end{array}$} & \multicolumn{4}{|c|}{$\begin{array}{l}\text { Lohman Brown } \\
\text { Penyimpanan (Hari) }\end{array}$} & \multirow{2}{*}{$\begin{array}{l}\text { Inter- } \\
\text { aksi }\end{array}$} & \multirow[t]{2}{*}{$\mathrm{SEM}^{(4}$} \\
\hline & $\mathrm{HO}^{(1)}$ & $\mathrm{H} 7$ & $\mathrm{H} 14$ & $\mathrm{H} 21$ & $\mathrm{HO}$ & $\mathrm{H} 7$ & $\mathrm{H} 14$ & $\mathrm{H} 21$ & & \\
\hline \multicolumn{11}{|l|}{ Eksterior } \\
\hline Berat (g) & $40,62^{\mathrm{a} 2)}$ & $40,61^{a}$ & $40,23^{a}$ & $40,56^{\mathrm{a}}$ & $63,16^{a}$ & $63,04^{\mathrm{a}}$ & $63,09^{a}$ & $63,10^{\mathrm{a}}$ & ns & 0,72 \\
\hline Kebersihan & $0,33^{b}$ & $0,38^{b(2)}$ & $0,25^{a b}$ & $0,11^{a}$ & $0,12^{\mathrm{a}}$ & $0,15^{\mathrm{a}}$ & $0,16^{\mathrm{a}}$ & $0,19^{a}$ & s & 0,006 \\
\hline Tekstur permukaan telur & $0,26^{a b}$ & $0,30^{\mathrm{b}}$ & $0,12^{\mathrm{a}}$ & $0,11^{a}$ & $0,12^{\mathrm{a}}$ & $0,16^{\mathrm{a}}$ & $0,17^{\mathrm{a}}$ & $0,19^{a}$ & s & 0,005 \\
\hline Indeks & $77,20^{\mathrm{a}}$ & $77,02^{\mathrm{a}}$ & $79,91^{\mathrm{a}}$ & $78,56^{\mathrm{a}}$ & $81,08^{a}$ & $80,02^{a}$ & $81,03^{a}$ & $81,73^{\mathrm{a}}$ & ns & 2,149 \\
\hline \multicolumn{11}{|l|}{ Interior } \\
\hline Tebal kerabang $(\mathrm{mm})$ & $0,328^{a}$ & $0,339^{a}$ & $0,346^{a}$ & $0,338^{a}$ & $0,346^{a}$ & $0,337^{a}$ & $0,339^{a}$ & $0,339^{a}$ & ns & 0,002 \\
\hline Berat kerabang(g) & $5,36^{\mathrm{a}}$ & $5,04^{a}$ & $5,97^{a}$ & $4,93^{\mathrm{a}}$ & $6,01^{\mathrm{a}}$ & $5,97^{a}$ & $6,09^{a}$ & $6,27^{a}$ & ns & 0,178 \\
\hline $\mathrm{pH}$ telur & $8,03^{a}$ & $7,50^{a}$ & $7,90^{\mathrm{a}}$ & $7,83^{\mathrm{a}}$ & $8,07^{a}$ & $8,26^{\mathrm{a}}$ & $8,09^{a}$ & $7,72^{\mathrm{a}}$ & ns & 0,305 \\
\hline Warna kuning & $8,80^{\mathrm{a}}$ & $8,68^{\mathrm{a}}$ & $9,80^{a}$ & $8,31^{\mathrm{a}}$ & $10,86^{a}$ & $10,32^{\mathrm{a}}$ & $10,76^{a}$ & $10,33^{\mathrm{a}}$ & ns & 0,893 \\
\hline $\mathrm{HU}$ & $79,14^{a}$ & $77,56^{a}$ & $78,23^{a}$ & $77,68^{a}$ & $80,21^{a}$ & $80,59^{b}$ & $80,66^{b}$ & $79,10^{\mathrm{ab}}$ & ns & 4,204 \\
\hline $\begin{array}{l}\text { Kandungan TPC mikroba } \\
\text { (CFU/g) }\end{array}$ & $1,49 \times 10^{2 a}$ & $1,53 \times 10^{2 a}$ & $1,56 \times 10^{2 a}$ & $1,65 \times 10^{2 a}$ & $1,42 \times 10^{1 a}$ & $1,56 \times 10^{1 a}$ & $1,39 \times 10^{1 a}$ & $2,00 \times 10^{1 a}$ & ns & 0,302 \\
\hline Grade & AA & AA & AA & AA & AA & AA & AA & AA & - & \\
\hline
\end{tabular}

Keterangan:

1) $\mathrm{HO}=$ lama penyimpanan 0 hari, $\mathrm{H} 7=$ lama penyimpanan 7 hari, $\mathrm{H} 14=$ lama penyimpanan 14 hari, $\mathrm{H} 21$ = Lama penyimpanan 21 hari

2) Superskrip yang sama pada baris yang sama berbeda tidak nyata $(P>0,05)$ dan superskrip yang berbeda pada baris yang sama menujukkan berpengaruh nyata $(P<0,05)$

3) Interaksi

4) SEM: Standart Error of the Treatmeant Means

antara telur ayam kampung dan telur ayam Lohman Brown berpengaruh signifikan terhadap tekstur permukaan telur. Hasil analisis tekstur permukaan telur menunjukkan hasil yang berbeda nyata $(\mathrm{P}<0,05)$ paling tinggi pada $\mathrm{H} 7$ pada ayam Kampung dan pada H21 pada ayam Lohman Brown.

Telur yang baru keluar dari tubuh induknya mempunyai mutu yang terbaik. Hal ini disebabkan keadaan kulit telur, besarnya ruang udara, kondisi putih telur dan kuning telur masih dalam keadaan normal. Semakin lama umur penyimpanan, mutu telur akan semakin menurun, karena terjadinya perubahan beberapa sifat kimia serta sifat fisik telur yang dipengaruhi oleh keadaan lingkungan tempat telur berada.

Tekstur permukaan telur juga bisa terjadi akibat umur induk ayam, dimana umur ayam mempengaruhi penyerapaan mineral pada saluran telur yang mengakibatkan saluran telur tidak lagi optimal menyerap nutrisi (mineral) dari pakan yang diberikan sehingga penyebaran mineral untuk pembentukan cangkang tidak merata dan menyebabkan permukaan telur yang tidak rata atau berbintil. Pakan ayam petelur fase layer harus mengandung 3-4\% kalsium (Harms et al., 1996), Pakan yang dikonsumsi pada umumnya sudah habis tercerna pada saat pembentukan cangkang. Kalsium pakan yang tertinggal di saluran pencernaan sangat sedikit. Jika absorbsi kalsium yang ada tidak memenuhi kebutuhan pembentukan cangkang, kalsium diambil dari tulang (Riczu dan Korver, 2009).

Indeks telur menunjukan perlakuan pada telur ayam kampung pelakuan $\mathrm{H} 14$ menunjukan angka tertinggi (79,91), sedangkan perlakuan Ho, H7, H21 berturut- turut 77,20; 77,02; dan 78,56 lebih rendah namun secara statistik menunjukan hasil yang tidak berbeda nyata $(\mathrm{P}>0,05)$. Sedangkan pada perlakuan pada telur ayam Lohman perlakuan tertinggi pada perlakuan H21 $(81,73)$ sedangkan perlakuan Ho, H7 dan $\mathrm{H} 14$ berturutturut 81,08; 81,02; 81,03; lebih rendah dari perlakuan H21 dan secara statistik menunjukan hasil yang tidak berbeda nyata $(\mathrm{P}>0,05)$.

Interaksi antara telur ayam kampung dan ayam Lohman tidak berpengaruh terhadap indeks telur yang disimpan sampai 21 hari pada suhu kamar antar perlakuan penyimpanan o hari, 7 hari, 14 hari, dan 21 hari baik telur ayam kampung maupun telur ayam Lohman.

Interaksi antara telur ayam Kampung dan ayam Lohman Brown tidak berpengaruh terhadap indeks telur yang disimpan sampai 21 hari pada suhu kamar antar perlakuan penyimpanan o hari, 7 hari, 14 hari, dan 21 hari baik telur ayam Kampung maupun telur ayam Lohman Brown. Hasil yang didapatkan baik sesuai dengan Murtijo (1992) yang menyebutkan bahwa indeks telur yang baik berkisar antara 70-79. Nilai indeks yang besar menunjukan bahwa telur tersebut memiliki bentuk yang lebih bulat sedangkan telur yang lebih lonjong memiliki nilai indeks telur yang lebih kecil. Nilai yang lebih kecil disebabkan karena bagian isi dalam telur yang tidak seimbang (Anonimous, 2011).

Bentuk telur unggas bermacam-macam, umumnya berbentuk hampir bulat sampai lonjong. Perbedaan bentuk ini terjadi karena adanya berbagai faktor yang mempengaruhi antara lain sifat genetik, umur unggas saat bertelur, serta sifat-sifat fisiologis yang terdapat dalam tubuh induk. Biasanya bentuk telur dinyatakan 
dalam indeks perbandingan antara lebar dan panjang dikalikan 100. Telur dari unggas yang berbeda menghasilkan ukuran yang berbeda pula. Faktor-faktor yang mempengaruhinya antara lain jenis unggas, umur, perubahan musim sewaktu unggas bertelur, sifat keturunan, umur pembuahan, berat tubuh induk dan pakan yang diberikan.

Hasil penelitian terhadap kualitas interior telur ayam kampung dan ayam Lohman Brown selama penyimpanan tersaji pada Tabel 1. Tebal kerabang pada ayam kampung pada $\mathrm{H} 14$ adalah o,346 yang lebih tinggi daripada Ho, H7, dan $\mathrm{H} 21$ berturut-turut 0,328, o,339, dan 0,338 dimana secara statistik tidak berbeda nyata ( $\mathrm{P}>0,05)$. Pada telur ayam kampung, tebal kerabang secara stastistik juga menunjukkan hasil yang tidak berbeda nyata $(\mathrm{P}>0,05)$, pada ayam Lohman Brown dimana Ho menunjukkan angka 0,346 lebih tinggi dari $\mathrm{H}_{7}, \mathrm{H} 14$, dan $\mathrm{H} 21$ dimana berturut-turut 0,337 ; o,339; 0,339 dan interaksi antara telur ayam kampung dan ayam Lohman tidak berpengaruh terhadap tebal kerabang telur ayam.

Pengaruh perlakuan terhadap kualitas interior telur seperti tebal kerabang memberikan hasil yang tidak berbeda nyata $(\mathrm{P}>0,05)$ (Tabel 1). Rataan tebal kerabang yang didapat berkisar antara $0,34-0,40 \mathrm{~cm}$ pada ayam kampung dan 0,39-0,45 cm pada ayam Lohman Brown. Kualitas kerabang telur dipengaruhi oleh kecukupan gizi ternak, kesehatan ternak, manajemen pemeliharaan, serta kondisi lingkungan peternakan. Kerabang telur mengandung sekitar 95\% kalsium dalam bentuk kalsium karbonat dan sisanya seperti magnesium, fosfor, natrium, kalium, seng, besi, mangan, dan tembaga (Gary et al., 2009).

Hasil penelitian yang diperoleh berada diantara hasil penelitian Stadeleman et al. (1973) yaitu 0,33cm. Secara umum kebutuhan kalsium untuk pembentukan kerabang telur sudah terpenuhi. Peningkatan kualitas kerabang telur dapat dicapai dengan menstablikan aliran kalsium ke pembuluh darah, hal ini dikarenakan sumber utama $\mathrm{CaCO}_{3}$ berasal dari ion bikarbonat dalam darah. Ion bikarbonat terbentuk dari reaksi antara $\mathrm{CO}_{2}$ dan $\mathrm{H}_{2} \mathrm{O}$ dalam darah dengan batuan enzim karbonik anhydrase (Blakely dan Bade, 1998). Tebal kerabang telur ayam Lohman berkisar antara 0,330 - 0,350 mm. Tebal kerabang telur dipengaruhi beberapa faktor yaitu: umur, tipe ayam, zat-zat makanan, peristiwa faal dari organ tubuh, stres, dan komponen lapisan kerabang telur. Kerabang yang tipis relatif berpori lebih banyak dan besar, sehingga mempercepat turunnya kualitas telur akibat penguapan dan pembusukan lebih cepat. Ketebalan kulit telur ayam Lohman normal adalah sebesar 0,33-0,35 mm (Steward dan Abbott, 1972).

Hargitai et al. (2011) menyatakan tebal tipisnya kerabang telur dipengaruhi oleh strain ayam, umur induk, pakan, stres dan penyakit pada induk. Salah satu yang mempengaruhi kualitas kerabang telur adalah umur ayam, semakin meningkat umur ayam kualitas kerabang semakin menurun, kerabang telur semakin tipis, warna kerabang semakin memudar, dan berat telur semakin besar (Yuwanta, 2010). Anon (2011) menyatakan masalah kerabang telur tipis dan lembek bisa bersumber dari nutrisi ataupun karena infeksi penyakit. Pada kerabang telur terdapat poripori. Banyaknya pori-pori per butir telur ayam Lohman berkisar antara 7.000 - 17.000 yang digunakan untuk pertukaran gas. Pori-pori tersebut berukuran 0,01 - 0,07 $\mu \mathrm{m}$ dan tersebar di seluruh permukaan telur. Kerabang telur pada bagian tumpul memiliki jumlah pori-pori per satuan luas lebih banyak dibandingkan dengan pori-pori bagian yang lain (Kurtini et al., 2011).

Hasil penelitian pada berat kerabang telur ayam kampung menunjukan H14 (5,97g) lebih tinggi dibandingkan dengan $\mathrm{Ho}_{7} \mathrm{H}_{7}$, dan $\mathrm{H}_{21}$ berturut-turut 5,36 g; 5,04 g; dan 4,93 g secara statistik tidak berbeda nyata $(\mathrm{P}>0,05)$. Pada telur ayam Lohman Brown, berat kerabang H21 $(6,21 \mathrm{~g})$ menunjukan lebih tinggi dibandingkan $\mathrm{Ho}, \mathrm{H}_{7}$ dan $\mathrm{H}_{14}$ berturut-turut 6,o1g; 5,97g; dan 6,09g dimana secara statistik menunjukan hasil yang tidak berbeda nyata $(\mathrm{P}>0,05)$ dan interaksi antara telur ayam kampung dan ayam Lohman tidak berpengaruh terhadap berat kerabang telur (Tabel 1).

Kerabang telur merupakan bagian terluar yang membungkus isi telur dan berfungsi mengurangi kerusakan fisik maupun biologis, serta dilengkapi dengan pori-pori kerabang yang berguna untuk pertukaran gas dari dalam dan luar kerabang telur (Sumarni dan Djuarnani, 1995). Komposisi kerabang telur terdiri atas $98,2 \%$ kalsium, o,9\% magnesium dan 0,9\% fosfor (Stadelman dan Cotteril, 1973).

Kerabang telur dilindungi oleh lapisan kutikula luar dan membran kerabang dalam (Yamamoto et al., 1996). Pada bagian kerabang telur ditemukan dua selaput (membran), yaitu membran kerabang telur (outer shell membrane) dan membran albumen (inner shell membrane) yang berfungsi melindungi isi telur dari infiltrasi bakteri dari luar (Kurtini et al., 2011).

Berat kerabang dipengaruhi oleh kandungan nutrien ransum, kesehatan, managemen pemeliharaan dan kondisi lingkungan. Cangkang telur mengandung sekitar 95\% kalsium dalam bentuk kalsium karbonat dan sisanya magnesium, fosfor, natrium, kalium, seng, besi, mangan, dan tembaga (Gary et al., 2009). Cangkang (shell) terdiri dari kutikula (cutcle), lapisan kapur busa (spongi calcareous layer) dan lapisan mamillaris (mammilary layer). Cangkang telur tersusun dari $94 \% \mathrm{CaCO}_{3}, 1 \%$ MgCO3, 1\% CaPO4, dan 4\% sisanya adalah bahan organik. Pembentukan cangkang telur membutuhkan penyediaan ion kalsium yang cukup dan adanya ion 
karbonat dalam cairan uterus (Hintono, 1995). Mineral banyak terdapat dalam cangkang telur adalah Kalsium. Defisiensi kalsium dapat menyebabkan kerabang telur menjadi tipis dan produksi akan menurun (Anggorodi, 1985).

Hasil penelitian pada $\mathrm{pH}$ telur ayam kampung menunjukkan Ho lebih tinggi $(8,03)$ dibandingkan $\mathrm{H} 7$, H14, H21 berturut-turut 7,50; 7,80; 7,93. Secara statistik tidak berbeda nyata $(\mathrm{P}>0,05)$. Pada telur ayam Lohman $\mathrm{H} 7$ memiliki rataan tertinggi $(8,26)$ dibandingkan dengan Ho, H14 dan H21 berturut-turut 8,07; 8,09; dan 7,72 secara statistik tidak berbeda nyata $(\mathrm{P}>0,05)$ dan Interaksi antara telur ayam kampung dan ayam Lohman tidak berpengaruh terhadap $\mathrm{pH}$ telur ayam (Tabel 1). Terhadap $\mathrm{pH}$ pada telur setelah mendapat perlakuan disimpan tidak berbeda nyata $(\mathrm{P}>0,05)$ hal ini dimungkinkan pada waktu penyimpanan hingga 21 hari pada suhu kamar tidak memberikan peluang terhadap mikroba untuk merombak protein maupun lemak pada telur ayam kampung maupun ayam Lohman Brown. Berbeda dengan kelembaban, semakin tinggi suhu maka $\mathrm{CO}_{2}$ yang hilang lebih banyak, sehingga menyebabkan $\mathrm{pH}$ albumen meningkat dan kondisi kental albumen menurun (Indratiningsih, 1984).

Penyimpanan dapat meningkatkan nilai $\mathrm{pH}$ telur. Meningkatnya nilai $\mathrm{pH}$ telur terjadi karena penguraian senyawa $\mathrm{NaHCO}_{3}$ menjadi $\mathrm{NaOH}$ dan $\mathrm{CO}_{2}$. $\mathrm{NaOH}$ yang dibentuk akan diurai menjadi $\mathrm{Na}+$ dan $\mathrm{OH}-$ sedangkan $\mathrm{CO}_{2}$ yang dibentuk akan menguap, sehingga meningkatkan $\mathrm{pH}$ albumen. Peningkatan $\mathrm{pH}$ tersebut akan membentuk ikatan kompleks ovomucin-lysozyme yang menyebabkan kondisi albumen menjadi encer (Budiman dan Rukmiasih, 2007).

Hasil penelitian pada warna kuning telur ayam kampung menunjukan H14 lebih tinggi $(9,80)$ dibandingkan Ho, H7, H21 berturut-turut 8,80; 8,68; 8,31 . Secara statistik tidak berbeda nyata $(\mathrm{P}>0,05)$. Pada telur ayam Lohman Ho memiliki rataan tertinggi $(10,86)$ dibandingkan dengan $\mathrm{H}_{7}, \mathrm{H} 14$ dan $\mathrm{H} 21$ berturut-turut 10,32, 10,76 dan 10,33 secara statistik tidak berbeda nyata $(\mathrm{P}>0,05)$ dan Interaksi antara telur ayam kampung dan ayam Lohman tidak berpengaruh terhadap warna kuning telur (Tabel 4.2). Pengaruh perlakuan terhadap warna kuning telur memperlihatkan hasil analisa sidik ragam antar perlakuan tidak berbeda nyata $(\mathrm{P}>0,05)$ baik ayam kampung maupun ayam Lohman. Warna kuning telur sendiri dipengaruhi oleh Xantophill dalam ransum yang dikonsumsi ayam saat dipelihara, sebagai mana dikatakan oleh Sudaryani (2003) warna kuning telur yang baik berkisar 9-12.

Argo dan Mangisah (2013) menyatakan warna kuning telur salah satunya dipengaruhi oleh kandungan xanthopyl, betacaroten, klorofil dan cytosan dari ransum. Adanya perbedaan warna kuning telur ini diduga disebabkan oleh perbedaan kemampuan metabolisme dalam mencerna ransum dan perbedaan dalam menyerap pigmen xantophyl dalam ransum. Selain itu, telur mengalami perembesan air dari putih telur ke kuning telur yang mengakibatkan perenggangan membran vitelin, sehingga volume kuning telur menjadi lebih besar yang mengakibatkan warna kuning telur menjadi pucat.

Hasil penelitian pada HU telur ayam kampung menunjukan Ho lebih tinggi $(79,14)$ dibandingkan $\mathrm{H} 7$, H14, H21 berturut-turut 77,56; 78,23; 77,68. Secara statistik tidak berbeda nyata $(\mathrm{P}>0,05)$. Pada telur ayam Lohman Brown $\mathrm{H} 14$ memiliki rataan tertinggi $(80,66)$ dibandingkan dengan Ho, H7 dan H21 berturut-turut 80,21; 80,59; dan 79,10 secara statistik berbeda nyata $(\mathrm{P}<0,05)$ pada Tabel 1 dan interaksi antara telur ayam kampung dan telur ayam Lohman berpengaruh signifikan terhadap HU $(\mathrm{P}<0,05)$. Interaksi ini disebabkan oleh genetik ayam Lohman yang berpengaruh terhadap lebar pori-pori kerabang yang berdampak pada penguapan didalam telur

Haugh Unit (HU) yang diperoleh dari telur ayam kampung maupun ayam Lohman Brown yang memperoleh penyimpanan sampai 21 hari memiliki skor berkisar 77-79 pada ayam kampung dan 78-80 pada ayam Lohman Brown. Nilai ini lebih tinggi dibandingkan skor 60 menurut Haugh (2004). Derajat kesegaran telur dibedakan menjadi tingkat AA memiliki skor $>72 \mathrm{HU}$, tingkat A memiliki skor 62-72 HU, tingkat B memiliki skor < 6o HU (Haugh, 2004). Dengan nilai HU di atas maka menunjukkan kualitas telur masih baik selama penyimpanan dan sesuai dengan grade yang diperoleh AA, semua perlakuan baik ayam kampung maupun ayam Lohman Brown.

Nilai HU pada telur ayam Lohman pada penyimpanan 14 hari nyata $(\mathrm{P}<0,05)$ lebih tinggi dari pada penyimpanan $\mathrm{o}, 7$, dan 21 hari. Hal ini dimungkinkan terjadi karena penurunan penguapan $\mathrm{CO}_{2}$ dan $\mathrm{H}_{2} \mathrm{O}$ dari dalam telur dikarenakan suhu kamar yang stabil. Normalnya, telur yang masih baru, pori-porinya masih dilapisi oleh lapisan tipis kutikula yang terdiri dari 90\% protein dan sedikit lemak. Fungsi kutikula untuk mencengah penetrasi mikroba melalui kerabang telur dan mengurangi penguapan air yang terlalu cepat (Sirait, 1986). Semakin lamanya waktu penyimpanan, semakin tingginya penguapan $\mathrm{CO}_{2}$ dan $\mathrm{H}_{2} \mathrm{O}$ sehingga putih telur semakin menurun kekentalannya. Pengenceran putih telur terjadi karena perubahan struktur gelnya, akibat kerusakan fisiko - kimia serabut ovomucin yang menyebabkan keluarnya air dari jala-jala yang telah dibentuknya. Telah diketahui bahwa ovomucin adalah glikoprotein berbentuk serabut dan dapat mengikat air membentuk struktur gel (Sirait, 1986).

Pada telur ayam kampung H21 memiliki rataan 
tertinggi $\left(1,65 \times 10^{2}\right)$ dibandingkan dengan $\mathrm{Ho}, \mathrm{H} 7$ dan $\mathrm{H} 14$ berturut-turut $1,49 \times 10^{2} ; 1,53 \times 10^{2} ; 1,56$ $\mathrm{x} 10^{2}$ secara statistik tidak berbeda nyata $(\mathrm{P}>0,05)$. Hasil penelitian pada mikroba telur ayam Lohman H21 menunjukan rataan tertinggi $\left(2,00 \times 10^{1}\right)$ dibandingkan dengan $\mathrm{Ho}, \mathrm{H}_{7}$, dan $\mathrm{H}_{14}$ berturut-turut $1,42 \times 10^{1}$; $1,56 \times 10^{1} ; 1,39 \times 10^{1}$ secara statistik tidak berbeda nyata ( $>>0,05)$ (Tabel 1). Kandungan TPC mikroba (cfu/g) pada Tabel 1 penyimpanan Ho, H7, H14 dan H21 pada suhu kamar mengalami peningkatan, baik telur ayam kampung maupun telur ayam Lohman Brown tidak berbeda nyata $(\mathrm{P}>0,05)$. Peningkatan total mikroba dari masing-masing penyimpanan telur disebabkan karena bahan makanan atau nutrien yang terkandung dalam telur masih tersedia dan adanya hasil metabolisme yang mungkin beracun dapat mengambat pertumbuhan dari bakteri itu sendiri. Persediaan air dalam telur yang mulai terbatas disebabkan terjadinya pengkristalan sehingga air tersebut tidak dapat diserap akibatnya bakteri mengalami kekurangan air (Fardiaz, 1992).

Perbedaan kondisi lingkungan di dalam tubuh induk dengan lingkungan di luar tubuh induk menyebabkan berbagai perubahan pada telur. Alat reproduksi induk mempunyai kelembaban yang tinggi dengan suhu yang hangat, sedangkan kondisi lingkungan di luar tubuh induk mempunyai keadaan yang lebih kering dan suhu yang lebih rendah. Terjadinya ruang udara dan pemisahan membran kulit luar dan dalam disebabkan perubahan suhu tersebut. Besarnya ruang udara dipakai sebagai atribut mutu telur. Permukaan kulit mula-mula diselimuti oleh cairan mukosa yang kental. Pada saat peneluran terjadi pengeringan mukosa tersebut. Pada saat masih basah mukosa mampu melindungi telur dari penetrasi air, gas dan bakteri melalui kulit (Yunita, 2015) dan karena jumlah total mikroba pada telur yang didapat masih dibawah standar yaitu $1 \times 10^{5}$ koloni maka telur tersebut masih layak dikonsumsi (Anonimus, 2007).

\section{SIMPULAN}

Berdasarkan hasil penelitian ini dapat disimpulkan bahwa (1) Kualitas telur ayam kampung dan ayam Lohman tetap memiliki kualitas baik dan masih layak dikonsumsi setelah disimpan selama 21 hari dengan Grade AA. (2) Lama penyimpanan berpengaruh terhadap kualitas eksterior dan interior telur dimana terdapat penurunan selama masa penyimpanan tetapi telur masih layak dikonsumsi. (3) Terjadi interaksi yang signifikan antara perlakuan dengan jenis ayam pada kebersihan telur dan tekstur permukaan telur ayam Kampung dan ayam Lohman Brown selama penyimpanan

\section{DAFTAR PUSTAKA}

Anggorodi, R. 1985. Kemajuan Mutakhir dalam Ilmu Makanan Ternak Unggas.PT. Gramedia. Jakarta

Anonimous. 2011. Telur dan Problematikanya. https:// info. Anonim. co. id/index. php/ artikel/ layer/ penyakit/ telur- dan- problematikanya. Diakses pada tanggal 15 Mei 2015

Budiman, C. dan Rukmiasih. 2007. Karakteristik Putih Telur Itik Tegal. Jurnal Seminar Nasional Peternakan dan Veteriner. Fakultas Peternakan. Institut Pertanian Bogor.

Fardiaz, S. 1992. Mikrobiologi Pangan 1. Gramedia Pustaka Utama, Jakarta.

Gary, D., D. V. M Butcher, dan R. Miles. 2009. Ilmu Unggas. Jasa Ekstensi Koperasi, Lembaga Ilmu Pangan dan Pertanian Universitas Florida. Gainesville.

Hadiwiyoto, S. 1983. Penanganan dan Pemanfaatan Limbah. Jakarta: Yayasan Idayu.

Haugh, R. R. 2004. The Haugh Unit for Measuring Egg Quality. U.S Egg Poultry Magazine. No.43, Pages 552-555 and 557-573. (1973)

Hargitai, R., R. Mateo, J. Torok. 2011. Shell thickness and pore density in relation to shell colouration female characterstic, and enviromental factors in the collared flyctcher ficedula albicolis. J. Ornithol.152:579-588.

Harms, R.H., C.R. Douglas, dan D.R. Sloan. 1996. Midnight feeding of commercial laying hens can improve eggshell quality. Journal of Poultry Applied Science Resources $5: 1-5$.

Jamila, F., K. Tangdilintin, dan R. Astuti, 2009. Kandungan protein kasar dan serat kasar pada feses ayam yag difermentasi dengan Lactobacillus sp. Seminar Nasional Teknologi Peternakan dan Veteriner, Bogor.

Kurtini, T., K. Nova., dan D. Septinova. 2011. Produksi Ternak Unggas. Universitas Lampung, Bandar Lampung.

Pelczar, M. J., dan E. C. S. Chan, 1988. Dasar-Dasar Mikrobiologi 2. Penerjemah: Hadioetomo, R. S. Universitas Indonesia Press. Jakarta Hal: 468-469.

Sirait, C. H. 1986. Telur dan Pengolahannya. Pusat Penelitian dan Pengembangan Peternakan. Bogor

Sarwono, 1995. Pengawetan dan Pemanfaatan Telur. Penebar Swadaya, Jakarta.

Sastrosupadi, A. 2000. Rancangan Percobaan Praktis Bidang Pertanian. Edisi revisi. Penerbit Kanisius, Yogyakarta.

Stadelman, W. J. and O.J. Cotteril, 1973. Egg Science and Technology. Mac Millan Publisher, UK.

Steward, G.F. and J.C. Abbott. 1972. Marketing Eggs and Poultry. Food and Agricultural Organization (FAO). The United Nations. Rome

Sudaryani, 2003. Kualitas Telur. Penebar Swadaya, Jakarta Yamamoto, T., L. Juneja, R. Hatta, and M. Kim. 1997. Hen Eggs. CRC Press. New York.

Yuanta, T. 2010. Telur dan Kualitas Telur. Gadjah Mada University Press.

Yunita. 2015. Penentuan mutu telur. http:// kulinologi. co. id/ acrobat/ index1. php? View \& id= 900. Diakses 2015 